\title{
Writing as a Supplement: Jacques Derrida’s Deconstructive Reading of Rousseau's Confessions
}

\author{
Gerasimos Kakoliris \\ University of Athens
}

\begin{abstract}
The present study constitutes a critical appraisal of the deconstructive reading of Rousseau's Confessions that Derrida undertakes in the second part of Of Grammatology. In this examination, the author will first list some of the significations into which Derrida disperses (forced, as he asserts himself, by an "inassimilable residue" in the text itself) the meaning that he has already construed as apparently simple during the first moment of deconstructive reading (i.e., "the doubling commentary"); the author will then go on to enquire into the operations which enable Derrida to arrive at these self-conflicting significations. The main aim of this essay is to demonstrate that it is not language alone that disables the philosophy of Rousseau and enables the philosophy of Derrida. When Derrida attempts to support his philosophy through an analysis of Rousseau's theory of language and the alleged contradictions in Rousseau's texts, he misinterprets basic tenets of these texts in order to make them conform to the presuppositions of the deconstructive approach. The "reversal” and "displacement" of metaphysical conceptuality in the text of the Confessions is made possible after the text has had meanings transposed into it from a plurality of other texts. Derrida attributes to the text significations he discovers by construing, explicating and over-reading passages that occur elsewhere in Rousseau's total oeuvre (especially in the Essay on the Origin of Languages).
\end{abstract}

Keywords: Derrida, Deconstructive Reading, Rousseau’s Confessions

\section{Deconstructing the Confessions}

According to Derrida, in the Confessions, one of the binary oppositions that Jean-Jacques Rousseau reproduces is that between speech and writing. Speech is elevated as the immediate, natural medium of linguistic expression par excellence, while writing is relegated to a mere supplement of speech. For Derrida, such a move is determined by the same logocentric gesture which has characterized the entirety of Western philosophical discourse from Plato through Rousseau to Saussure and Levi-Strauss in which writing is an unproductive representation of speech which lacks immediacy.

Yet, when Rousseau, on Derrida's reading, attempts to justify his authorial activity, it becomes immediately clear that speech is not always successfully related to the positivity of full presence. Rousseau is obliged to take refuge in writing which provides him with an absence and a type of calculated effacement in an attempt to create a symbolic reappropriation of a certain presence that speech "should" possess. Rousseau thinks that he is able to express himself less successfully when he is present than when he is writing. When he

Gerasimos Kakoliris, lecturer, Dr., Department of Philosophy, Faculty of Philosophy, Pedagogy \& Psychology, School of Philosophy, University of Athens, Greece; main research field: Contemporary French Philosophy (Derrida, Foucault, Levinas, etc.), Theories of Reading, and Theories of Hospitality. Email: gkakoliris@ppp.uoa.gr. 
talks, he is often obliged to say things that he does not mean, which results in the generation of a false image of who he actually is (OG 142/DLG 205). ${ }^{1}$

As a result, Rousseau attempts to master the absent presence of speech through his own absence. Such an absence is possible only through the absence effectuated by writing. Consequently, it is writing that is closer to the mark of presence than speech. Yet, although, in a sense, Rousseau is obliged to rehabilitate writing to the extent that it promises the reappropriation of that presence which speech is allowed to be dissembled, however, it is a re-establishment of a presence in speech as it "should" be, or such as it "should have been" that is his ultimate goal (OG 215/DLG 308). Rousseau, thereby, simultaneously valorizes and disqualifies writing. He must eventually exorcise all those features in writing which could undermine this effort of re-appropriation of presence in speech. As a result, Rousseau proceeds to define writing (as the supplement of speech), as mere external addition, a simple exteriority (OG 167/DLG 237-8).

Hence, according to Derrida, Rousseau conceives writing as a dangerous medium, a threatening form of assistance. When speech fails to protect presence, writing reveals its necessity. Since speech is the natural expression of thought, writing adds to it; it is joined to speech as a representation or an image, and to that effect, as something unnatural. The addition of writing to speech constitutes a kind of artificial and ingenious deceit in order to render speech present when in fact it is not. Writing is dangerous from the moment when representation presents itself as presence, taking the place of speech. Writing inevitably covers over its status as a supplement and presents itself as synonymous with the completeness of speech.

Yet, although Rousseau's declared intention is to think speech as unique and remaining intact by the exteriority of writing, "in spite of that declared intention, Rousseau's discourse lets itself be constrained by a complexity which always has the form of the supplement of or from origin” (OG 243/DLG 345). The notion of the supplement - determining here the notion of writing as descriptive image-shelters another meaning whose cohabitation with the first is both strange and necessary. The supplement is added in order to complete, to compensate for a lack in that which is deemed self-sufficient, complete in itself. The possibility of the addition of the supplement indicates that what is supplemented is incomplete or absent.

From his own description of speech, Rousseau, on Derrida's reading, should have concluded that writing, lack, difference have "always already" corrupted speech from inside. However, Rousseau prefers to believe that speech "must (should) have been plenitude and not lack, presence without difference” (OG 215/DLG 308). As a result of this conclusion, which valorizes speech as a desideratum, writing is described as something secondary, "add[ing] itself from the outside as evil and lack to happy and innocent plenitude. It would come from an outside which would be simply the outside” (OG 215/DLG 308).

Although writing is external to the interiority of speech, it can, however, affect it in its interiority. For Derrida, Rousseau's remarks on the exteriority of writing to speech and the threat that writing poses to full speech, despite its declared exteriority, are conditioned by the same contradictory logic exhibited in Western philosophical discourse from Plato to Saussure and Levi-Strauss. This contradictory logic leads Rousseau to maintain both the exteriority of writing and the power of its noxious infiltration, its ability to affect or infect.

Yet, it does not suffice to say, as Derrida observes, "that Rousseau thinks the supplement without thinking it, that he does not match his saying and his meaning, his descriptions and his declarations” (OG 245/DLG 348). Rather, the tension between the gesture and the statement, the description and the declaration, instead of leading to their mutual annihilation, contributes to the cohesion of the text through the "ought to be" or the conditional mood (OG 295/DLG 416). In this form, Rousseau can think both incompatible possibilities, namely presence 
and supplement, together. As the conditional mood reveals, this contradictory coherence is itself the fulfillment of a desire: "And as always, coherence in contradiction expresses the force of a desire” (Derrida 1978, 279). Derrida views this kind of contradictory logic as analogous to what Freud, in The Interpretation of Dreams and Jokes and Their Relation to the Unconscious, calls the "sophistry of the borrowed kettle." As Derrida explains, "In his attempt to arrange everything in his favor, the defendant piles up contradictory arguments: 1 . The kettle I am returning to you is brand new; 2 . The holes were already in it when you lent it to me; 3 . You never lent me a kettle, anyway” (Derrida 1981, 110).

According to Derrida, Rousseau organizes his various arguments referring to presence and supplement, speech and writing, in an analogous way: 1 . The supplement and writing are rigorously exterior and inferior to presence and speech, which are thus not affected by them and remain intact; 2 . They are harmful because they are separate from presence and, thereby, affect and infect living speech which would otherwise remain intact; 3. Anyway, if one need to resort to supplement and writing at all, it is not for their intrinsic value, but because presence is already deficient, it already has holes in it before writing ever comes to supplement it. Hence, supplement and writing have no effect in presence or speech at all (Derrida 1981, 110; Gasché 1986, 132).

The "logic of supplementarity" is Derrida's attempt to tie all these contradictory declarations and propositions about presence and supplement, or speech and writing together into a structure in such a way as not only to avoid obliterating them, but also, to explicitly account for their possibility and the limits of their scope. The "structure of supplementarity," as the act of addition and vicarious substitution of an absent presence, seeks to explain the contradictions that result from assuming both the simple exteriority of the supplement and its threat to absent presence. This structure is composed of a field of relations that inscribes within itself the function and value of the philosophical notion of original presence or presence in general; it shows how the myth of an untainted original presence, or presence in general, depends upon the annihilation of the "logic of supplementarity" (OG 167/DLG 238).

\section{2. “... That Dangerous Supplement”}

The same "paradoxical” logic of the supplement reappears when Rousseau discusses his "secret vice," the habit of substituting solitary pleasures for the experience of a "natural" eroticism determined according to heterosexual norms. Rousseau condemns masturbation as a perverse, pernicious, and overpowering addition. The indulgence of autoerotic fantasy is a way of "cheating nature" through the substitution of the presence of a sexual partner with a simple image (absence): “... Soon reassured, I learned that dangerous means of assisting it (ce dangereux supplément), which cheats nature and saves up for young men of my temperament many forms of excess at the expense of their health, strength, and, sometimes, their life" (Confessions, 108-9; ${ }^{2}$ OG 150/DLG 215). This is because it "summons up absent beauties," allowing the fantasist to multiply imaginary experiences beyond all the limits of a wise, self-regulated nature (OG 151/DLG 216).

Rousseau is unwilling to admit that the supplement may be there at the source or that such undoubted "perversions" of nature may infect every order of natural morality. Nevertheless, despite his insistence on their pure exteriority to an (interior) nature, he does not miss the opportunity to underline-falling into the same contradictory logic as he describes for the relationship between writing and speech-their destructive impact on the latter. But, how is it possible for masturbation or sexual fantasy, which is foreign, completely exterior to the interiority of a self-sufficient nature, to be capable of altering it, thus making it deviate from itself? As Derrida notes: "Rousseau neither wishes to think nor can think that this alteration does not simply happen to the self 
that it is the self's very origin. He must consider it a contingent evil coming from without to affect the integrity of the subject” (OG 153/DLG 221).

For Derrida, despite Rousseau's declared intentions, the Confessions presents another Rousseau, one who is inescapably dependent upon fantasy —as indeed he is upon writing - to compensate for a lack which is always there at the heart of sexual desire. For it is there, in Rousseau's complaint that his experience with women has never lived up to those images of passionate fulfillment that throng his sleeping and waking fantasy-life. Reality always comes to represent a certain falling-short, a failure of desire in the very act of attaining its wished-for object. Rousseau reveals that his desire arises in inverse proportion to the natural proximity of the woman he desires: "I only felt the full strength of my attachment to her when she was out of my sight” (OG 152/DLG 218). In this way, the desire for the possession of a "real” woman, a desire founded and generated by distance, repeats the fundamental structure of masturbation — desire of an imagined object that one can never "possess" except in his fantasy. In this sense, sexual activity in general can be seen, as Jonathan Culler in On Deconstruction elegantly describes, "as moments of a generalized masturbation" in the same way that language is a generalized writing (Culler 1983, 104). In order for something to function as a substitute, it must resemble in some essential way that which it replaces.

It is not merely the fact that a desire's fulfillment appears, in Rousseau, to be impossible, it is also devastating: "If I had ever in my life tasted the delights of love even once in their plenitude, I do not imagine that my frail existence would have been sufficient for them. I would have been dead in the act” (Confessions, 210; OG 155/DLG 223). Thus, Rousseau will explain how he has resorted to the pleasures of a guilty, unnatural practice only on account of his susceptibility towards women. He fears that such a possible excess of passion can overwhelm his nature. His declared intention is to explain this weakness through his own "frail existence" or his psychopathology of aberrant desire. However, in the process of describing this (supposedly untypical) series of accidents, Rousseau's text deviates from its author's declared intentions resulting in a presentation in which "human sexuality is always and everywhere a kind of 'supplementary' experience, one that can never be traced back to a source in a moment of pure, natural fulfillment” (Norris 1987, 199).

\section{Against a Trans-textual Reading of the Confessions}

In "The Exorbitant Question of Method," the extended methodological note that accompanies his reading of Rousseau's Confessions, Derrida claims that although reading "must not be content with doubling the text," it cannot, however "legitimately" ("légitimement”), endorse a trans-textual reading, a reading which would transgress the text towards something other than itself: either to a referent, "a reality that is metaphysical, historical, psychobiographical, etc.," or to "a signified outside the text whose content could take place and could have taken place outside of language, that is to say, in the sense that we give here to that word, outside of writing in general” (OG 158/DLG 227).

The rejection of a trans-textual reading stems, as Derrida himself notes, from the general propositions which he elaborates in the first part of Of Grammatology "as regards the absence of the referent or the transcendental signified" (OG 158/DLG 227). In making this remark, Derrida thus renders clear that the most appropriate way to elucidate the meaning of his famous pronouncement that "there is nothing outside the text" (OG 158/DLG 227) is in relation to the non-existence of the "transcendental signified.” Moreover, according to Derrida, in this so-called transgression of the text toward an external referent or signified, "it has moreover only believed it was doing so by illusion” (OG 163/DLG 234). For Derrida, reading “must be intrinsic and remain 
within the text" (OG 159/DLG 228). It must not move in the direction of the discovery of a supposed signified content. Reading must not transgress the text toward a pre-linguistic, ahistorical, independent reality similar to the Kantian thing-in-itself (das Ding-an-sich).

There are, of course, ironies and paradoxes entailed in Derrida's criticism. If everything can be considered a text, if there is nothing outside the text, then, why "must [reading] be intrinsic and remain within the text”? If reading "has moreover only believed it was doing so [leaving the text] by illusion" (OG 163/DLG 234), why should we insist on the existence of a danger in regard to which nobody is in danger? We are thus faced with the following paradox: While, on the one hand, Derrida declares, "there is nothing outside the text," he, on the other hand, still insists that reading "must be intrinsic and remain within the text."

In claiming that a text's "outside" is another text, it is deconstruction itself which provides a passage for the transcendence of a particular text toward its "outside." If we accept that the transcendence of the empirical text toward its "outside" is hitherto made in the name of a transcendental signified, in the case of deconstruction, the transcendence of the empirical text toward its outside is now justified by the claim that everything is "text." Therefore, if a text's "outside" is another text, why must reading avoid moving toward this "outside"? Why must it remain "intrinsic"? The generalization of the text only precludes the "illusion" that this "outside" can function as a transcendental signified mastering the meaning of the text. If the text's "outside" cannot be distinguished from its "inside," if the "inside" contains its "outside" and vice-versa, then Derrida's exhortation that reading "must be intrinsic and remain within the text" is rather incongruous. Moreover, it is Derrida himself who grounds his notion of "intertextuality" in the deconstruction of the opposition between a text's "inside" and "outside." As he has stated on several occasions, the written text "circulates through other texts, leading back to it constantly” (circulant à travers d' autres textes, y renvoyant sans cesse) (OG 149/DLG 214). Yet, there are other reasons which can explain why for deconstruction a reading "must be intrinsic and remain within the text," reasons which are not, however, commanded by Derrida's claim that "there is nothing outside the text” (DLG 227/OG 158).

In reading Rousseau's life-history, as he narrates it himself in the Confessions, there is a great temptation to endorse a type of psychoanalytic reading which would "take us outside of the writing toward a psychobiographical signified, or even toward a general psychological structure that could rightly be separated from the signifier" (OG 159/DLG 228). Yet, as we have already noted, since this "psychobiographical signified" is itself a text, even if the psychoanalytic critic thinks otherwise, why must we object to such interpretations, even though they have been stripped of their pseudo-absolute, "illusionary," character? Why should not we accept them as mere interpretations among other plausible interpretations? Why is it not enough to point out that they are not absolute?

When Derrida claims that reading "must be intrinsic and remain within the text," his motives are of a different kind. Deconstructive reading must be "intrinsic" since it must produce the "signified structure" of the text under deconstruction. Yet, this exhortation exceeds the limits of a mere description of the technical necessities of the deconstructive process in order to be incorporated into Derrida's "quasi-transcendental" argument about the conditions of possibility and impossibility of the distinction between a text's "inside" and "outside." And as such, it is deconstructed by the same argument to which it alludes.

Certainly, a disproportionate engagement with the "extra-textual" conditions of a text's production, even when it is made in the knowledge that these "extra-textual" conditions are themselves "writing," can function against the text itself. In the effort to elucidate a text's relationship with its "outside," there is always the danger 
of "losing," the former in the latter. That is, a text's particularity (and this is not necessarily limited to its thematic content) can be "absorbed" by its "outside." Therefore, we should not substitute the biography of the author of a text or the socio-historico-political conditions of its production for the text itself. ${ }^{3}$

Behind his "quasi-transcendental" argument about a text's "outside"- "there is nothing outside the text”-Derrida's opposition to a transcendental type of reading, such as the psychoanalytic one, a reading that is totally directed toward a psychopathological signified, is determined by the fact that such a reading treats the bond of the psychopathological signified with its graphic signifier as entirely external and symptomatic. Hence, a deconstructive reading differentiates itself through its aim to grasp the "production" of a text's "signifying structure" (OG 158/DLG 227). It must avoid, according to Derrida, the lure of treating the text as a mere "symptom," as an additional "expression" of an individual psyche, and as a consequence, remaining blind "to the very tissue of the 'symptom,' to its proper texture” (OG 159/DLG 228). For Derrida, "the habitual psychoanalysis of literature begins by putting the literary signifier as such within parentheses” (OG 160/DLG 230). ${ }^{4}$ Moreover, for Derrida, in the case of the examination of Rousseau's texts, a reading of a psychoanalytic type would be unable to locate "all the structures of appurtenance within Rousseau's text, all that is not unique to it—by reason of the encompassing power and the already-thereness of the language or of the culture-all that could be inhabited rather than produced by writing" (OG 161/DLG 230). Namely, it would be unable "to elucidate the law of its own appurtenance to metaphysics and Western culture” (OG 161/DLG 231).

\section{Life as Writing}

According to Derrida, the "guiding line of the "dangerous supplement"' leads to recognition that the so-called "reality," life itself, in its materiality, even as it is lived, all that which lies outside the empirical text, functions as writing. Derrida's claim is that even Rousseau's life is determined by the structure of "supplementarity" or différance. What could be named as Rousseau's "life" is nothing but an endless series of supplements: The presence of Thérèse is, for example, a supplement for the absence of "Mamma;" the presence of "Mamma" is a supplement for the absence of a "natural" mother, while the presence of a "natural" mother is the supplement of that absent mother who Rousseau invokes in Emile.

What we call Rousseau's life, with its socio-economical conditions and public events, its private sexual experiences and its acts of writing, is conditioned by the "logic of supplementarity." If Derrida prompts us to perceive "real" life on the base of the model of the text, if he claims that "there is nothing outside the text" is because this "outside" (whether we call it reality, experience, etc.) is constituted of further supplements or chains of supplements (OG 158-9/DLG 224). Both the "outside" and the "inside" are constituted by the multiplying results of supplementarity, something that puts into question the accuracy of a rigid opposition between "inside" and "outside." 5

Derrida's position is not limited to ascertaining that Rousseau's "real life,” as well as anything else which we call "reality,” is presented to our perception only through concepts. In “... That Dangerous Supplement...," Derrida attempts to show that his views on the constitution of concepts presented in the first part of Of Grammatology are confirmed by a text that is not of a similar subject-matter. Derrida wants to demonstrate that his theory of signification in the first part of Of Grammatology and all that it has excluded (as, for example, the existence of an absolute or natural presence) is confirmed by looking at what is called "real life." Hence, looking at "real life," through Rousseau, he finds that, for example, "the absolute present, Nature, that which words like 'real mother' name, have always already escaped, have never existed; that what opens meaning and 
language is writing as the disappearance of natural presence” (OG 159/DLG 228).

But how is it possible for Derrida to justify the kind of correspondence that he establishes between a theory of signification and that which he would call "real life" "under erasure" ("sous rature")? Why should Rousseau's "real life," in its materiality, obey the "logic of supplementarity” or différance? It is true that both reality and the text, or the text and what lies "outside" it, are immersed in language. Yet, Derrida wants to make a wider claim without explaining or justifying it sufficiently, if he actually explains or justifies it at all: that "in what one calls real life... 'of flesh and bone,' ... there has never been anything but writing” (OG 159/DLG 228). But, claiming that the "world," "reality," "experience," or "life” cannot be thought outside the supplement of language is not the same as turning the "world," "reality," "experience,” or "life," as they are lived, into a labyrinth of supplements. Nevertheless, if Derrida wants to take this further step, that is, to turn the world into a series of supplements, he has to offer reasons as a means of justifying why it is so: Description is not explanation or justification. Is it, thus, possible for Derrida to exclude the possibility that the presence of the supplement, both in Rousseau's effort to retrace an origin for language and his narration of his life, is not accidental? Derrida needs to explain whether the presence of the supplement in Rousseau's "life" is due to his peculiar psychopathology or whether there is some other necessity that makes its presence inescapable. Moreover, is this to be taken as peculiar to Rousseau or as a principle that conditions lived experience in general? If it is a principle that conditions lived experience in general, how can the claim that "in what one calls real life... 'of flesh and bone,' ... there has never been anything but writing” be extended beyond Rousseau's Confessions in order to gain a general force?

\section{Examining the Accuracy of Derrida's Reading of the Confessions}

Derrida urges us to "think Rousseau's experience and his theory of writing together, the accord and the discord that, under the name of writing, relate Jean-Jacques to Rousseau, uniting and dividing his proper name" (OG 144/DLG 207). In practice, this means that, "we must therefore think... together" the Confessions and the Essay on the Origin of Languages. If we compare these two texts, one finds, according to Derrida, that while in the Confessions, writing is used as a means to re-establish a lost presence, in the Essay, writing is blamed as a “destruction of presence.” Even when Rousseau accepts its necessity and takes refuge in it, he still feels uncomfortable with it since he would prefer the primary presence guaranteed by a "full speech" ("parole dite pleine") to the dangerous assistance of writing (OG 141/DLG 204). Yet, this simultaneous "valorization" and "disqualification" of writing is not so "strange" as it is declared above, since Derrida adds that "the strange unity of these two gestures" is accounted for by the word "supplement” (OG 144/DLG 207).

Derrida has already made clear that "The names of authors or of doctrines have here no substantial value. They indicate neither identities nor causes... The indicative value that I attribute to them is first the name of a problem" (OG 99/DLG 147-8). Thus, the exhortation to "think... together" the Confessions and the Essay, that which joins together Rousseau's life and his theory of writing, is not related to the proper name "Rousseau"- the unificatory consciousness of a writer - but it is based on the similar and supplementary way in which these two different texts treat the supplement of writing or supplementarity in general. Hence, the unity of the Confessions and the Essay seems to be explained by the fact that "In both cases, in fact, Rousseau considers writing as a dangerous means, a menacing aid, the critical response to a situation of distress" (OG 144/DLG 207).

Despite Derrida's exhortation to "think... together" these two texts, we ought to distinguish carefully 
between what belongs to the Confessions and what belongs to the Essay. In such a placing together of two different texts, there is always the danger of an interpretive overdetermination of one text by the other. Here, Derrida's interpretation of the Essay also comes to determine his interpretation of the Confessions. This is because the accusation against writing that Derrida attributes to Rousseau finds no support if one concentrates solely upon a reading of the Confessions. Assertions of the type "this recourse (to writing) is not only 'bizarre,' but dangerous... It is a violence done to the natural destiny of the language” (OG 144/DLG 207), which can be supported by an interpretation of the Essay, find no place within the Confessions. Nowhere in the Confessions does Rousseau put forward any kind of valuation concerning writing. Nowhere does he characterize writing as a "dangerous means" or a "menacing aid," as Derrida claims. In order to make the Confessions say what he wants it to say, Derrida is obliged to refer constantly and disproportionately to other texts by Rousseau, particularly to the Essay. Thus, Derrida exhorts us to "think... together" the Confessions and the Essay, because without this jointure, the Confessions, would be unable to offer by themselves an indictment of writing.

The supposed condemnation of writing in the Confessions, is based solely on a few lines. In this way, Derrida's pursuit of the theme of writing in this particular text is "exorbitant.” Rousseau's sole reference to writing is in the form of a short explanation of the reasons which leads him to the writing of his autobiography:

I would love society (J'aimerais la société) like others, if I were not sure of showing myself not only at a disadvantage, but as completely different from what I am. The part that I have taken of writing and hiding myself is precisely the one that suits me. If I were present, one would never know what I was worth. (Confessions, 115-6) (OG 142/DLG 205)

The first interpretive impropriety, on Derrida's part, is the neglect of the section within which this passage is set. Immediately prior to the passage, Rousseau confesses:

I think that I have sufficiently explained why, though I am not a fool, I am very often taken for one, even by people in a good position to judge. Unfortunately for me too, my face and my eyes seem to promise otherwise, and people find my stupidity all the more shocking because it disappoints their expectations. This fact, which explains one situation in particular, is not irrelevant to what follows. It presents the key to a great number of my strange actions, which witnesses have attributed to morose disposition that I do not possess. I should enjoy society as much as anyone, if ... (Confessions, 115-6)

While even earlier, Rousseau has undertaken to explain the reasons for this uncomfortable position in which he finds himself. In moments of heightened emotion, he loses his ability to think and to express himself adequately:

... if I want to think I must be cool. The astonishing thing is, though, that I have considerable tact, some understanding, and a certain skill with people so long as they will wait for me. I can make excellent replies impromptu, if I have a moment to think, but on the spur of the moment I can never say or do anything right. I could conduct a most delightful conversation by post, as they say the Spaniards play chess. (Confessions, 113)

Or, even worse:

But what is even more fatal is that, instead of keeping quiet when I have nothing to say, it is at just those times that I have a furious desire to chatter. In my anxiety to fulfill my obligations as quickly as possible, I hastily gabble a few ill-considered words, and am only too glad if they mean nothing at all. So anxious am I to conquer or hide my ineptitude that I rarely fail to make it apparent. (Confessions, 115)

Rousseau explains that the fact that he hides himself through writing is not due to misanthropy. He tells us that he loves society like others. Hence, we are not confronted here with the manifestation of any preference for 
speech over writing. In the paragraph under examination, Rousseau's main aim is to explain the reasons for which he is forced to write his autobiography. If he writes his Confessions - thus Rousseau does not speak about writing in general as Derrida attempts to show - it is in order to repair the false picture that others have about him, since, when he is present, for the reasons he explains above-he gives an impression about himself different from what he really is. Writing in the safety of his shelter, he finds easier to produce a picture of himself that conforms to the view which he has of himself.

Derrida's argument that Rousseau installs the binary opposition between speech and writing at the heart of the Confessions only functions through the detachment of this controversial passage and its isolation from its wider context. According to Derrida, Rousseau would prefer the presence guaranteed by the living speech of the face-to-face relation to the deferred, impersonal presence guaranteed by writing. That Rousseau eventually chooses the "menacing aid" of the supplement of writing is due to a certain feeling of inferiority on his part. Yet, nowhere in the Confessions does Rousseau declare that writing is inferior to speech, that the supplement of writing is "dangerous," or that he generally prefers the presence guaranteed by speech to the one guaranteed by writing. Rousseau explicitly and clearly explains the reasons why he writes his autobiography. Nowhere does he say or imply that he would prefer not to write. Neither does he declare that writing is a "dangerous" form of expression that one should attempt to avoid.

This does not prevent Derrida from asserting that, for Rousseau, "when speech fails to protect presence, writing becomes necessary" (OG 144/DLG 207). But only then? Rousseau does not say that if he could express himself sufficiently through speech, then he would not take recourse to writing at all. Rousseau's stated reasons for the writing of the Confessions are related to the failure of speech to protect truth, but this does not imply that the role of writing is limited, or ought to be limited, to these exceptional cases, namely, when and insofar as speech has failed.

In the sole passage devoted to writing, and, more specifically, to the reasons governing the writing of the Confessions, the recourse to writing is not characterized as "bizarre" and "dangerous," nor is a single negative judgment against writing made. There is no "indictment against the negativity of the letter" (OG 144/DLG 207) put forward, but, on the contrary, writing is praised for its ability to answer to an uncomfortable position which Rousseau confronts. The passage, which Derrida cites, does not trace a binary opposition between speech and writing, nor attribute any priority to speech in relation to writing, nor provide any explicit or implicit reference to writing as a "dangerous supplement," a "menacing aid," or an "artificial and artful ruse."

Writing is nowhere explicitly named as a supplement in the Confessions. Yet, this is something, which is, as Derrida claims, implied by the way writing is implicitly described. But what is exactly the nature of the supplementation that writing performs? It has already been mentioned that Rousseau's aim is to replace the mis-representation of himself with a true picture of himself acquired through writing. This kind of supplementation enacted by writing is radically different from the classical kind of supplementation described in the Essay on the Origin of Languages, according to which writing is held up as the consolidation of language through the substitution of its oral signs by written ones. While writing may be added to speech in order to restore the distorting effects of the latter, this does not necessarily entail that it is, therefore, the depiction or the representation of speech through writing.

It is not that Rousseau, due to his specific disability, is forced to entrust all that he would prefer to express through speech to writing. Rousseau does not decide to write simply and exclusively about what he would have otherwise preferred to speak about. One is not confronted here with the duplication of a spoken discourse in 
writing. Rousseau makes recourse to writing, or he prefers to "hide himself in writing," in order to explicate why he "messes it up" every time he tries to speak in front of others; he wants to state the effects that this strange disability has on his public image, and to repair it by substituting it for the one he tries to create through a written portrayal of his life. Hence, in this case, writing does not constitute a supplement of speech in a classical sense. Therefore, Derrida's analogy between the supplement of writing described in the Confessions and the supplement of writing described in the Essay or Rousseau's other texts seems problematic.

Derrida does not limit his description of what is said about the "supplement" of writing in the Confessions to the sole passage that explicitly refers to it. Derrida attempts to re-establish the function of the concept of the "supplement" in general (even beyond the specific "supplement" of writing, and even beyond the text of the Confessions). Derrida's reading of the function of "supplementarity" in Rousseau's sexual life and its correlation with the "supplement" of writing has already been alluded to. Derrida's final conclusion is that in all these cases of supplementarity, the "way" in which Rousseau "determines" the concept of the "supplement” and "in so doing, lets himself be determined by that very thing that he excludes from it, the direction in which he bends it, here as addition, there as substitute, now as the positivity and exteriority of evil, now as a happy auxiliary," "tricks” with the same "gesture of effacement” (OG 163/DLG 234). Hence, when, for example, one compares the way in which the supplement of writing is described in reference to the experience of Rousseau as an author with his autoerotic experience, one is led to the conclusion that "those two supplements have in common at least the fact that they are dangerous” (OG 165/DLG 235).

But they are "dangerous" also in another and more significant sense. Any attempt to control them ends in failure. The "supplement" is dangerous because it refuses its "exteriority," the derivative and "secondary" role attributed to it. This explains why all these different but, at the same time, similar descriptions of the "supplement" by Rousseau, are deconstructible. So, the examination of particular cases in the light of a more general context aims at making visible those structures responsible for their similarities.

There is no doubt that the correlation of apparently different moves and the discovery of a common structure that conditions them is, in some cases, particularly illuminating. Nevertheless, this particular way of reading, this strange intertextuality, this interweaving of heterogeneous passages or texts through the tracing of the function of a certain concept, runs the risk of being reductive. This is a danger lurking in Derrida's claim about the existence of a structure which conditions the entirety of the history of Western philosophy, and, in his exhortation to "think Rousseau's experience and his theory of writing together," the Confessions and the Essay on the Origin of Languages, the "supplement" of writing and the "supplement" of masturbation and other cases of supplementation in Rousseau's corpus.

In our critical appraisal of Derrida's reading of the Confessions, we have already taken the risk of putting forward the claim that if Derrida refers to other uses of the concept of the supplement in the Confessions (or even in other Rousseauian texts) besides that of writing, this is because the passages from the Confessions which refer to writing are incapable of supporting a reading according to which Rousseau condemns writing as a "dangerous supplement" of speech. Derrida's "ruse" is the following: Since the particular passage from the Confessions which refers to writing is not in itself sufficient to substantiate the denunciation of writing, Derrida takes other passages from the text (or from other texts) which will provide this substantiation through their linkage to an apparently common concept, namely, in this particular case, that of "supplement." In this way, from Rousseau's description of masturbation as a "dangerous supplement," he will articulate the dangerousness of the "supplement" in general, and then, as a consequence, the dangerousness of the supplement of writing. 
The constant fusion of different cases that Of Grammatology performs functions in order to bring about an ineluctable con-fusion about levels and demarcations, which help the production of a certain effect.

In this manner, a certain passage is interwoven with other passages, other texts, upon which Derrida systematically draws in his reading. The effect is to introduce a certain fluidity to the notion of the boundaries of a certain passage or text. This interweaving is itself predicated upon a structure which is presupposed from the beginning so that the interpretation of the particular cases is always already determined by it.

This is evident in another of Derrida's readings of the Confessions. In this particular case, Derrida wishes to show that the supplement in Rousseau occupies an intermediate position between total presence and total absence. He affects this through the following quotation from the Confessions:

Ah, my Thérèse! I am only too happy to possess you, modest and healthy, and not to find what I never looked for. [The question is of "maidenhood” (pucelage) which Thérèse has just confessed to have lost in innocence and by accident.] At first I had only sought amusement; I now saw that I had found more and gained a companion. A little intimacy with this excellent girl, a little reflection upon my situation, made me feel that, while thinking only of my pleasure, I had done much to promote my happiness. To supply the place of my extinguished ambition, I needed a lively sentiment which should take complete possession of (literally "fill”-remplit) my heart. In a word, I needed a successor to mamma. As I should never live with her again, I wanted someone to live with her pupil, in whom I might find the simplicity and docility of heart which she found in me. I felt it necessary that the gentle tranquility of private and domestic life should make up to me for the loss of the brilliant career which I was renouncing. When I was quite alone, I felt a void in my heart, which it only needed another heart to fill. Destiny had deprived me of, or, at least in part, alienated me from, that heart for which Nature had formed me. From that moment I was alone; for with me it has always been everything or nothing. I found in Thérése the substitute (supplément) that I needed. (OG 156-7/DLG 226; Confessions, 310-1)

In relation to this passage, Derrida states that:

The intermediary is the mid-point and the mediation, the middle term between total absence and the absolute plenitude of presence... the supplement occupies the middle point between total absence and total presence. The play of substitution fills and marks a determined lack. (OG 157/DLG 226)

Does Derrida grasp this relation adequately? Has Thérèse, as a "supplement," taken a position between "everything or nothing" as Derrida claims? Since the loss of his "mamma” who represented "everything” for him, Rousseau was obliged to stay alone since the guiding principle in his life was that if he could not have everything, he preferred having nothing. This continued until he encountered, in the person of Thérèse, the supplement for his "mamma," something that made him feel that he had everything again. "Blinded" by the desire to find that evidence which will validate and strengthen his explication of the function of the concept of the "supplement" in Rousseau, Derrida misinterprets the role Thérèse plays as a "substitute" in the passage, by arguing that she (as a supplement) "occupies the middle point between total absence and total presence.” Yet, for Rousseau, it is clear: If he had decided to be alone, it was because he did not wish to make any compromise. He waited until he "found in Thérèse the substitute (supplèment) that (he) needed." That is, he found a substitute for his "mamma," so he could have "everything” again. Therefore, the "supplement" in this passage plays exactly the opposite role to that which Derrida attaches to it; it is on the side of "plenitude" and not on the side of the "intermediary" as Derrida interprets it.

Derrida's generalization of the dangerousness of the supplement to include writing is arbitrary. This, in turn, leads Derrida to make wider assertions, which diverge radically from Rousseau's treatment of writing in the Confessions: "Within the chain of supplements, it was difficult to separate writing from onanism. Those two supplements have in common at least the fact that they are dangerous. They transgress a prohibition and are 
experienced within culpability" (OG 165/DLG 235). In particular, the extension of the dangerousness of masturbation, as a supplement of the heterosexual love relationship, to other forms of supplementation, and, in particular, to the supplement of writing, is unfounded and is based entirely on the misinterpretation of certain passages of the Confessions and, in particular, on the sole passage in which Rousseau explicitly refers to writing, when he undertakes to explain the reasons for writing his autobiography. This misinterpretation expands its effects through the accordance of interpretative predominance to this particular determination of the concept and the displacement of its other determinations or uses in the same text or in others. ${ }^{6}$

\section{Notes}

1. The abbreviation OG refers to Jacques Derrida. Of Grammatology. Trans. Gayatri C. Spivak. Baltimore: John Hopkins University Press, 1976; and DLG to Jacques Derrida, De la Grammatologie. Paris: Les Éditions de Minuit, 1967.

2. The abbreviation Confessions refers to Jean-Jacques Rousseau. The Confessions. Trans. J. M. Cohen. London: Penguin Books, 1953.

3. In "Cogito and the History of Madness," Derrida remarks that prior to our decision to cross the threshold of a text's historical context, there must be an "internal, rigorous, and exhaustive analysis" of the discourse of the text itself (of the "sign itself" as he says) in order for the text not to be falsified by its contextual determination (Derrida 1978, 44-45).

4. Yet, the same could be said of deconstructive reading: Deconstruction's interest in literary texts in no way promotes their literary element.

5. According to Barbara Johnson "for what Rousseau's text tells us is that our very relation to 'reality' already functions like a text. Rousseau's account of his life is not only itself a text, but it is a text that speaks only about the textuality of life. Rousseau's life does not become a text through his writing: it always already was one. Nothing indeed can be said to be not a text” (Derrida 1981, xiv).

6. I would like to thank Dr. Peter Langford for his invaluable help.

\section{Works Cited}

Culler, Jonathan. On Deconstruction: Theory and Criticism after Structuralism. London: Routledge, 1983.

Derrida, Jacques. “Structure, Sign and Play in the Discourse of the Human Sciences.” Writing and Difference. Trans. Alan Bass. Chicago: University of Chicago Press, 1978.

---. “Plato’s Pharmacy.” Dissemination. Trans. Barbara Johnson. Chicago: Chicago University Press, 1981.

Gasché, Rodolphe. The Tain of the Mirror: Derrida and the Philosophy of Reflection. Cambridge: Harvard University Press, 1986. Norris, Christopher. Derrida. London: Fontana Press, 1987.

Rousseau, Jean-Jacques. The Confessions. Trans. J. M. Cohen. London: Penguin Books, 1953. 